\title{
POST-MODERNISM AND NEPAL'S EDUCATION
}

Shreeram P. Lamichhane and Mana P. Wagley*

Abstract

The postmodernist critique of science consists of two interrelated arguments: epistemological and ideological. Both are based on subjectivity. First, because of the subjectivity of the human object, anthropology, according to the epistemological argument, cannot be a science; and in any event the subjectivity of the buman subject precludes the possibility of science discovering objective truth. Second, since objectivity is an illusion, science, according to the ideological argument, subverts oppressed groups, females, ethnics, third-world peoples etc.

The greatest accomplishment of postmodernism is the focus upon uncovering and criticizing the epistemological and ideological motivations in the social sciences.
Post-modernism

John Lechte in his book 'Fifty Contemporary Thinkers' (1994), drawing on the thoughts of Jean-Francois Lyotard and Jean Baudrillard, offers the concept of post-modernity as a questioning of modernist paradigm. This questioning, as he argues, differs due to individuals' perceptual difference in giving meaning to a certain object. Sandra Kerka (1997) views post modernism as a form of 'questioning, an attitude, or perspective'. These elements reflect naturalistic characteristics of post modernism, which essentially rebuffs grand narratives such as capitalism, Marxism, Christianity and questions the possibility of order in life and living and denies the existence of objective knowledge. Post-modernism favors mininarratives which explain small practices, local events, rather than large-scale universal or global concepts. These mini-narratives are always situational, provisional, contingent and temporary, making no claim to universality, truth, reason or stability. Post-modernists are suspicious of authoritative definitions of any trajectory of events. In other words, post modern philosophy shuns objectivity, rationality and science and the knowledge perceived by modernism which calls for reason and science does not get any recognition in the post modern realm because knowledge, as the post modernism asserts, is subjective construct founded on the language engineering.

\section{Modernity and Post-modernity}

Postmodernism surfaced as a rejection of modernism and modernism on the other hand came out as a result of its disagreement with pre-modernity views. Authority and tradition were the two major ingredients of pre-modernity which were required to be respected by individuals. Negation of these pre-modernity prescriptions as a result of humanist enlightenment of $18^{\text {th }}$ century which discarded authority and tradition in favor of reason and science introduced the notion of modernism. We can see the schematic differences of modernism and post-modernism from the following table given by Hassan (1985):

* School of Education, Kathmandu University 
Table 1

\section{Schematic Differences between Modernism and Postmodernism}

\begin{tabular}{|l|l|}
\hline \multicolumn{1}{|c|}{ Modernism } & \multicolumn{1}{c|}{ Postmodernism } \\
\hline $\begin{array}{l}\text { romanticism/ } \\
\text { symbolism }\end{array}$ & Para-physics/Dadaism \\
\hline purpose & play \\
\hline design & chance \\
\hline hierarchy & anarchy \\
\hline matery, logos & exhaustion, silence \\
\hline $\begin{array}{l}\text { art object, finished } \\
\text { word }\end{array}$ & process, performance \\
\hline distance & participation \\
\hline creation, totalization & deconstruction \\
\hline synthesis & antithesis \\
\hline presence & absence \\
\hline centering & dispersal \\
\hline genre, boundary & text, inter-text \\
\hline semantics & rhetoric \\
\hline paradigm & syntagm \\
\hline hypotaxis & parataxis \\
\hline metaphor & metonymy \\
\hline selection & combination \\
\hline depth & surface \\
\hline interpretation & against interpretation \\
\hline reading & misreading \\
\hline signified & signifier \\
\hline lisible (readerly) & scriptible \\
\hline narrative & anti-narrative \\
\hline grande histoire & petite histoire \\
\hline master code & idiolect \\
\hline symptom & desire \\
\hline type & mutant \\
\hline genital, phallic & polymorphous \\
\hline paranoia & schizophrenia \\
\hline origin, cause & difference-difference \\
\hline God the Father & The Holy Ghost \\
\hline Metaphysics & irony \\
\hline determinacy & indeterminacy \\
\hline transcendence & immanence \\
\hline & \\
Sorce Hs, & (ind \\
\hline
\end{tabular}

Source: Hassan, I., (1985), The Culture of Postmodernism. In Theory, Culture and Society, 2, pp. 123-4.
Hereagain, structural order and processes followed along the modernism philosophy and knowledge have proved fallible since numerous problems in the lived-reality of human beings have remained adamant. This fallibility of modernism gave way to the emergence of postmodernism which, according to John Daniel (UNESCO Assistant Director-General for Education, 2001-2004) recognizes the knowledge that is functional.

The following table describes the differences between modernity and post-modernity thinking:

Table 2

Contrast of Modern and Postmodern Thinking

\begin{tabular}{|l|l|l|}
\hline Reasoning & \multicolumn{1}{|c|}{ Modern } & \multicolumn{1}{|c|}{ Postmodern } \\
\hline tiom founda- & $\begin{array}{l}\text { Multiple fac- } \\
\text { tors of mul- } \\
\text { tiple levels } \\
\text { of reasoning. } \\
\text { Web-oriented. }\end{array}$ \\
\hline Science & $\begin{array}{l}\text { Universal Opti- } \\
\text { mism }\end{array}$ & $\begin{array}{l}\text { Realism of } \\
\text { Limitations }\end{array}$ \\
\hline Part/ Whole & $\begin{array}{l}\text { Parts comprise } \\
\text { the whole }\end{array}$ & $\begin{array}{l}\text { The whole is } \\
\text { more than the } \\
\text { parts }\end{array}$ \\
\hline God & $\begin{array}{l}\text { Acts by violating } \\
\text { "natural" laws" } \\
\text { or by "imma- } \\
\text { nence" in every- } \\
\text { thing that is }\end{array}$ & $\begin{array}{l}\text { Top-Down } \\
\text { causation }\end{array}$ \\
\hline Language & Referential & $\begin{array}{l}\text { Meaning in } \\
\text { social context } \\
\text { through usage }\end{array}$ \\
\hline
\end{tabular}

Source: http://private.fuller.edu/ - clameter/phd/ postmodern.html

\section{Post-modernism and Knowledge}

The language of post-modernism is rooted in the meaning in social context through usage. Post-modernism is concerned with questions of organization of knowledge. In a post-modern 
society, knowledge becomes functional in the sense that we learn things not to know them but to use that knowledge. The modernists' advocacy that knowledge is important within itself finds no place in post modern perspective, for the value of knowledge the post modernists acknowledge lies in its functionality pertaining to meeting subjective needs. Therefore, as against modernists' stance on objectivity post modernists stick to subjectivity. Demystification is the greatest accomplishments of post-modernism which focus upon uncovering and criticizing the epistemological and ideological motivations in the social sciences.

\section{Post-modernism and Education}

Looking at the formal and non-formal structures of learning we find them loaded with inelasticity. This stagnant situation has posed a strong challenge to the call for 'education for all' because we have witnessed a large mass of school age children still unschooled and illiterate adult population denied of literacy opportunities. The relevance of Ivan Illich's (1972) postmodernist view of de-schooling society failed to percolate into the reflective thinking of the educationists which could have addressed the world's concern that nobody is left behind without an education. Those who have the opportunity to get into the learning streams, be it formal or non-formal, are constrained by the prescriptive contents, although needs-based learning is advocated. They are led to read the word and least to read the world. Reflective practice in learning is fairly overlooked and thus denying them to discover new culture and knowledge from the prevailing ones. Similarly, the post modernist perspective on education argues in favor of such themes of learning as 'respect for diversity', 'appreciation of the equal value of all human beings', 'toleranceand respect for the freedom of others' and 'creativity, emotion and intuition' (Daniel, 2002). Daniel also suggests "Education must be a window on the world. It must draw out the potential of each individual and develop the skills and knowledge that will help the learners to find fulfillment in the various facets of life." He further states "Education must help us learn to live together, to create networks of social relationships and to work together in communities for the common good."

\section{Post-modernism and Educational Policy of Nepal}

Now let us examine the relevance of postmodern views for the attainment of full education specifically in the context of Nepal. We have witnessed Nepal's educational policy falling short of catching up with the high velocity of changes fueled by instantaneous production of knowledge and invention of technologies. The policy structure continues to be centrally dominant. The need for paradigmatic shift in the policy structure by deconstructing the existing static structure in order to make it more dynamic and forward looking has fallen outside of the consciousness of the policy makers. Similarly, the policy implementation structure has met the same fate. This reality has resulted into a mismatch between what education we need and what has been provided.

\section{Implications}

In essence, emancipation from oppressed reality, individual autonomy in projecting one's own destiny, creation of new knowledge and skills for better living through reflective practice, respect for dignity and egalitarianism, etc. are some of the major implications of post modernist education. Obsession with status quo and obduracy for the regulation of one's own identity serve as sources of conflicts and contention. The modernist curricula, despite the claim that they are change prone, seem to have been driven to follow the authority and tradition, hence nurturing status quo. It will simply be a mirage to fulfill our ambition for meaningful change unless the post modernist principle of deconstruction in the entire educational system with focus on constructivism afterwards with adequate attention towards adopting new educational 
premises as advocated by post modernism are wholeheartedly subscribed.

\section{Some Key Figures and Their Narratives}

These narratives are drawn from an article "Postmodernism and its critics" by Shannon Weiss and Karla Wesley.

Jean-Francois Lyotard : The Postmodern would be that which in the modern invokes the unpresentable in presentation itself, that which refuses the consolation of correct forms, refuses the consensus of taste permitting a common experience of nostalgia for the impossible, and inquires into new presentations--not to take pleasure in them, but to better produce the feeling that there is something unpresentable.

Jean Baudrillard: Everything has already happened....nothing new can occur, or there is no real world. We live in a world of images but images that are only simulations. We have now moved into an epoch... where truth is entirely a product of consensus values, and where science itself is just the name we attach to certain modes of explanation.

Jacques Derrida: A text employs its own strategems against it, producing a force of dislocation that spreads itself through an entire system. Reason is dominated by a metaphysics of presence.

Michel Foucault: What most people think of as the permanent truths of human nature and society actually change throughout the course of history.

Nancy Scheper-Hughes: Anthropologists, no less than any other professionals, should be held accountable for how we have used and how we have failed to use anthropology as a critical tool at crucial historical moments. It is the act of "witnessing" that lends our word its moral, at times almost theological, character.

\section{Our Narrative}

Mana Prasad Wagley and Shreeram Prasad Lamichhane: Those who have the opportunity to get into the learning streams, be it formal or non-formal, are constrained by the prescriptive contents, although needs-based learning is advocated. They are led to read the word and least to read the world. Reflective practice in learning is fairly overlooked and thus denying them to discover new culture and knowledge from the prevailing ones.

\section{References}

Daniel, J. (2007) http://portal.unesco.org/education. Accessed on 1 August, 2007.

Hassan (1985). "The Culture of postmodernism”. Theory, Culture, and Society, 2, 123-4.

Illich, I. (1972). De-schooling society. San Fransisco: Harper \& Row.

Kerk, S. (1997). http://cete.org/acveldoogen.asp Accessed on 12 July, 2007.

Lamichhane, S. P. \& Wagley, M. P. (2005). "Education and Post-modernism”. The Kathmandu Post.

Lechte, J. (1994). Fifty contemporary thinkers. London: ECHP HEE.

Lyotard, J. (1984) The Postmodern Condition: A Report on Knowledge. Manchester: Manchester University Press.

Weiss, S. \& Wesley K. Postmodernism and its critics. mdmurphy@tenhoor.as.ua.edu.

Contrast of modern and post-modern thinking. Retrived from http://private.fuller.edu/-clameter/phd/ postmodern.html on 17 July, 2007. 